\title{
NEW COMBINATIONS AND SYNONYMS IN NEOTROPICAL LEJEUNEACEAE (MARCHANTIOPHYTA), WITH DESCRIPTION OF LEJEUNEA TAMASII, A NEW SPECIES FROM BARRO COLORADO ISLAND, PANAMA
}

\author{
M. Elena ReINER-DreHWALD, Noris SALAZAR Allen \\ $\&$ Clementina Chung C. $\uparrow$
}

\begin{abstract}
The new species Lejeunea tamasii M. E. Reiner, N. Salazar Allen \& C. Chung C. from Barro Colorado Island, Panama, named in honor of Professor Tamás Pócs, is described and illustrated. Lejeunea tonduzana (Steph.) M. E. Reiner, comb. nov. (basionym: Hygrolejeunea tonduzana Steph.), L. recurva M. E. Reiner, nom. nov. (basionym: Hygrolejeunea recurva Steph. ex Bonner, nom. inval., H. herzogii Steph. 1916, nom.illeg.), and new synonyms in Lejeunea cerina (Lehm. \& Lindenb.) Gottsche, Lindenb. \& Nees (=Hygrolejeunea aspera Steph., = H. similis Steph.) and Lejeunea flava (Sw.) Nees (= Hygrolejeunea bahiensis Steph.) are proposed. Descriptions and illustrations for Lejeunea tonduzana and L. recurva are also provided.
\end{abstract}

Key words: liverworts, Lejeunea, new species, Panama, Hygrolejeunea, synonyms, tropical America

M. Elena Reiner-Drehwald, Albrecht-von-Haller-Institut für Pflanzenwissenschaften, Systematische Botanik, Untere Karspüle 2, 37073 Göttingen, Germany; e-mail: mreiner@uni-goettingen.de

Noris Salazar Allen \& Clementina Chung C., Smithsonian Tropical Research Institute, P.O. Box 0843-03092, Balboa, Ancón, Panama, Republic of Panama; e-mail: salazarn@si.edu

\section{INTRODUCTION}

The liverwort and hornwort flora of Panama comprises approx. 349 taxa (Stotler et al. 1998; Dauphin et al. 2006; Dauphin 2007). This number is relative low when compared to the rich liverwort and hornwort flora (approx. 590 taxa) of adjacent Costa Rica (Dauphin 2005), as already commented by Dauphin et al. (2006). Additional fieldwork in Panama, especially in areas of difficult access like Darién, Northern Veraguas and forests of the Central Cordillera will probably raise the number of species registered for the country (e.g., SchäferVerwimp 2012). Also revisions of incompletely known genera, like Lejeunea Lib., will increase our knowledge of the hepatic diversity in Panama, as shown below.

During field work in Barro Colorado, Panama, over 20 years ago, Salazar Allen and Chung collected a small liverwort, growing on rocks on two different trails of the island. It is now recognized as a species of Lejeunea, the largest genus within the family Lejeuneaceae (Reiner-Drehwald 1999). Although numerous papers dealing with this genus and related taxa have been published recently (e.g., Reiner-Drehwald \& Schäfer-Verwimp 2008; Pócs 2010; Renner et al. 2011; Heinrichs et al. 2012), there are still many names in need of revision. The genus Hygrolejeunea (Spruce) Schiffn., for example, has been known for over 20 years as a synonym of Lejeunea (Grolle 1988), and the status of many species have been recently updated (e.g., Reiner-Drehwald \& Ilkiu-Borges 2007; Reiner-Drehwald 2011). However, more than 20 species of Hygrolejeunea have not been transferred to other genera or synonymized as yet.

The Barro Colorado Natural Monument in Panama is one of the most famous and studied sites of tropical rainforests worldwide (Leigh et al. 1983; Anonymous 1992). It includes the Barro Colorado Island and adjacent peninsulas. The Island is located between the Atlantic and Pacific Oceans 
$\left(9^{\circ} 09^{\prime} \mathrm{N}, 79^{\circ} 51^{\prime} \mathrm{W}\right)$ and it is the largest island in Gatun Lake in the Panama Canal (Croat 1978).

Seven species of Lejeunea have been registered for the island, namely Lejeunea adpressa Nees (as L. magnoliae), L. smaragdina Besch. \& Spruce and L. tapajosensis Spruce (det. Reiner-Drehwald, cited by Dauphin et al. 2006), and L. laetevirens Nees \& Mont., L. maxonii (A. Evans) X.-L. He, L. minutiloba A. Evans and L. ulicina subsp. bullata (Taylor) R. M. Schust. (Stotler et al. 1998). But the Lejeunea collected by Salazar Allen and Chung in the island differs morphologically from these taxa, and also from all the other Lejeunea and Hygrolejeunea types and specimens from tropical America studied by the first author, and is therefore proposed here as a new species.

The aim of this paper is to describe the species of Lejeunea from Barro Colorado as L. tamasii, sp. nov. and propose new combinations and synonyms for Neotropical Lejeuneas, based on the study of types and additional collections.

\section{NOVELTIES IN LEJEUNEAS FROM TROPICAL}

\section{AMERICA}

\section{Lejeunea tamasii M. E. Reiner, N. Salazar Allen} \& C. Chung C., sp. nov.

Fig. 1

TyPe. PANAMÁ. Prov. Panamá. Isla Barro Colorado, Zona del Canal, $9^{\circ} 10^{\prime} \mathrm{N}, 79^{\circ} 50^{\prime} \mathrm{W}$, camino R. Shannon. Sobre roca, $200 \mathrm{~m}$ desde la Quebrada Shannon; 4 March 1987, N. Salazar Allen 4281 (HOLOTYPE: PMA; ISOTYPE: GOET; autoicous, perianths). Idem, Camino J. Van Tyne 13. Sobre piedra en quebrada seca; 25 March 1987; N. Salazar Allen \& C. Chung C. 4583 (PARATYPE: PMA, GOET). Idem, Sendero J. Van Tyne 9. Sobre piedra, en quebrada seca; 25 March 1987, N. Salazar Allen \& C. Chung C. 4623 (PARATYPE: PMA, GOET).

ETYMOLOGY. The new species is dedicated to Professor Tamás Pócs, an indefatigable bryologist, expert in the family Lejeuneaceae.

Plants dull, green to brownish in herbarium, 2-5 mm long, 0.7-1.2 mm wide; branches of the Lejeunea-type, few, similar or smaller than the main shoot, collars small. Stems 70-80 $\mu \mathrm{m}$ wide, epidermal cells in ventral view rectangular, $25-40 \times 35-50 \mu \mathrm{m}$; stems in cross section sub- orbicular, 7 rows of epidermal cells surrounding 9-10 rows of smaller medullary cells, epidermal cells $17-20 \times 20-25 \mu \mathrm{m}$, medullary cells $7-10 \times$ 10-12 $\mu \mathrm{m}$; ventral merophyte 2 cells wide. Leaves contiguous to imbricate, widely spreading. Lobes ovate, plane to slightly concave in ventral view, 400-600 $\mu \mathrm{m}$ long, 300-450 $\mu \mathrm{m}$ wide, margin entire, apex rounded, plane, dorsal margin arched, ventral margin \pm straight. Marginal leaf cells \pm rectangular, 15-20 × 17-25 $\mu \mathrm{m}$, median and basal cells similar in size, isodiametric to elongated, 15-25 $\times 25-40 \mu \mathrm{m}$; cell walls thin, trigones small, lacking intermediate thickenings, cuticle smooth; oil bodies not observed. Lobules usually reduced to a small, 2-3-celled basal triangle and a 1-2 cells long filament, the upper cell elongated, $10-12 \times 25-35 \mu \mathrm{m}$, and a long, 7-10 × 20-25 $\mu \mathrm{m}$ apical hyaline papilla; lobules seldom well developed, rounded-rectangular, inflated, $100 \mu \mathrm{m}$ long, $75 \mu \mathrm{m}$ wide, less than $1 / 4$ the lobe length, lateral margin slightly incurved, apical tooth oval, small, hyaline papilla apical to ental on the tooth, apical margin straight, 2 cells long, keel straight or slightly arched, entire, at the union with the ventral margin of the lobe not angled. Underleaves distant, appressed and curved on the stem, \pm oval, 110-125 $\mu \mathrm{m}$ wide, $150-175 \mu \mathrm{m}$ long, longer than wide, $1.5 \times$ the stem width, $30-50 \%$ bifid, sinus V-shaped, narrow, lobes triangular, straight, apex acute, formed by 1-2 cells in a row, margins toothed, 1-3 elongated teeth on each side, teeth often \pm elevated, base cuneate, insertion line covered by a pronounced rhizoid disc, occasionally with rhizoids. Autoicous, few fertile shoots found. Fertile shoots with numerous gametoecia, nearly one gynoecium at base of each vegetative leaf. Androecia terminal on innovations, small, globose, 2-3 pairs of imbricate bracts, bracteoles could not be observed. Gynoecia terminal on lateral branches on the shoot, without vegetative leaves at base, one innovation, probably lejeuneoid-type (first appendage is a lateral leaf), innovation mostly short and ending in an androecium, seldom sterile and long. Female bract lobe oval, margin entire, apex rounded; bract lobule small, oval, apex rounded to acute; bracteole oval to subrectangular, shortly bifid, margin toothed. Perianth \pm half its length 


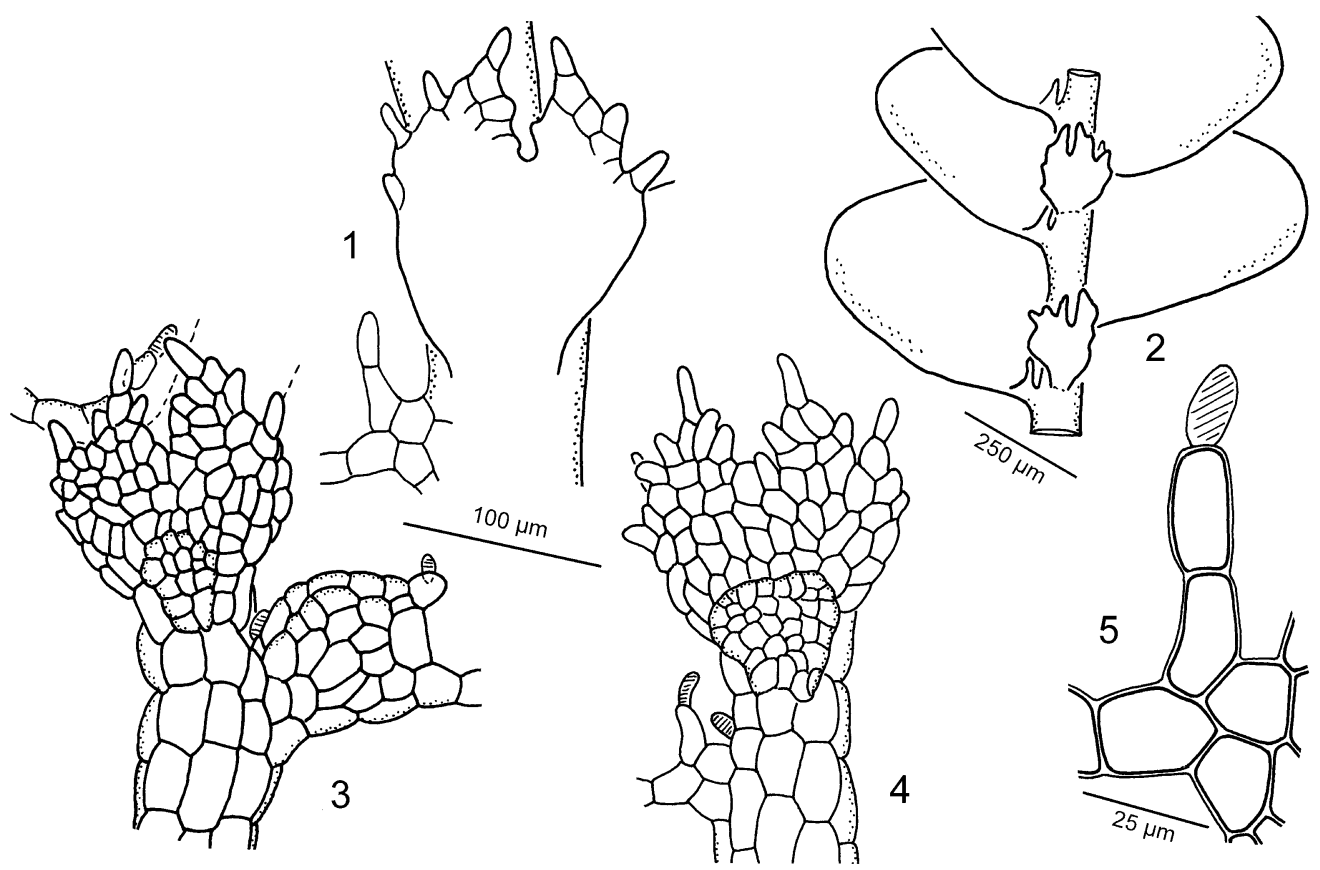

Fig. 1. Lejeunea tamasii M. E. Reiner, N. Salazar Allen \& C. Chung C., sp. nov. 1 \& 4 - underleaves with adjacent reduced ventral lobules, 2 - sector of shoot with reduced ventral lobules, 3 - underleaf with adjacent well developed lobule, 5 - reduced lobule with apical hyaline papilla. (All from Salazar Allen 4281, holotype).

emergent between the bracts, obovoid, inflated, 300-360 $\mu \mathrm{m}$ wide, 650-750 $\mu \mathrm{m}$ long, margin slightly crenulate due to globose cells, 5-keeled, keels $1 / 3$ the length of the perianth, dorsal keel less distinct, keels entire, beak not seen (broken ?). Sporophyte not observed. Vegetative reproduction not observed.

DISTRIBUTION AND ECOLOGY. Lejeunea tamasii is thus far known from only three collections from Barro Colorado, Panama, at 50-100 meters. It was found growing on rocks, on dry creeks, along two different trails in the Island. In one of the collections (Nr. 4583) it was growing with Fissidens weirii Mitt. and F. guianensis Mont. (det. C. Chung C. 1990).

Discussion. The description of Lejeunea tamasii should be considered preliminar, as it is based on three collections with few fertile shoots and mature perianths. The underleaves and lobules are also difficult to observe, as they are usually covered by algae and soil.
The distinctive characters of Lejeunea tamasii are found in the underleaves, that are appressed and curved on the stem and have toothed margins, with the teeth apex often slightly elevated from the underleaf plane. The underleaf margin in most species of Lejeunea is entire, but species with a \pm blunt or conspicuous tooth on the margin are also known, e.g., L. boryana Mont. and L. laetevirens Nees \& Mont. (Reiner-Drehwald 2000; ReinerDrehwald \& Goda 2000). In Lejeunea multidentata M. E. Reiner \& Mustelier the underleaf margins are also toothed, but the leaf shape with teeth and cilia on the margins clearly differs from the entire leaves of L. tamasii (Reiner-Drehwald \& Mustelier Martínez 2004).

2. Lejeunea tonduzana (Steph.) M. E. Reiner, comb. nov.

Fig. 2

Hygrolejeunea tonduzana Steph., Hedwigia 35: 105. 1896. TYPE: COSTA RICA, Río Naranjo, 200-250 m, March 1893, Tonduz 3077 a (HOLOTYPE, G 11832 [autoicous, c.per.]; ISOTYPE, JE [autoicous, c.per.]; both 
types intermingled with Lejeunea adpressa Nees [autoicous, c.per.]).

Plants shiny, brownish in herbarium, 0.8$1.4 \mathrm{~mm}$ wide; branches of the Lejeunea-type, \pm abundant, similar or smaller than the main shoot, collars small, most branches fertile. Stems 60-85 $\mu \mathrm{m}$ wide, epidermal cells in ventral view rectangular, 25-35 × 40-65 $\mu \mathrm{m}$; ventral merophyte 2 cells wide. Leaves imbricate, widely spreading. Lobes ovate, slightly concave, 450-700 $\mu \mathrm{m}$ long, 300-500 $\mu \mathrm{m}$ wide, margin entire, slightly crenate, apex rounded, plane, occasionally recurved, dorsal margin arched, ventral margin straight. Marginal leaf cells quadrate to rectangular, median cells isodiametric or elongated, $20-28 \times 33-40 \mu \mathrm{m}$, basal cells slightly larger; cell walls thin, trigones medium sized, 0-2 intermediate thickenings per wall; cuticle smooth; oil bodies not observed. Lobules variable, when well developed triangular, strongly inflated, 110-130 $\mu \mathrm{m}$ long, $80-100 \mu \mathrm{m}$ wide, $\pm 1 / 4$ the lobe length, lateral margin incurved, apical tooth $15 \times$
$25 \mu \mathrm{m}$, hyaline papilla proximal, apical margin 2-3 cells long, keel straight to slightly arched, at the union with ventral margin of lobe slighlty angled or straight; reduced lobules only few cells large. Underleaves distant, suborbicular, 160-225 $\mu \mathrm{m}$ wide, 140-190 $\mu \mathrm{m}$ long, wider than long or longer than wide, $2-3 \times$ the stem width, $25-45 \%$ bifid, sinus mostly U-shaped, lobes triangular, straight, 1 cell at the apex, 5-6 cells at the base, margins entire, base cuneate, insertion line slightly arched, rhizoids often developed. Autoicous. Androecia terminal on short branches without vegetative leaves at base, 2-3 pairs of bracts, bracts imbricate, hypostatic, 1 (or more?) bracteoles at base of spike, 2 antheridia per bract. Gynoecia terminal on short branches without vegetative leaves at base, one sterile innovation of the lejeuneoid-type. Female bracts and bracteole most broken. Perianths emergent $1 / 2-1 / 3$ its length between the bracts, \pm clavate, inflated, constricted at $1 / 2-1 / 3$ its length, 230-320 $\mu \mathrm{m}$ wide in the bottom, $350-450 \mu \mathrm{m}$ wide
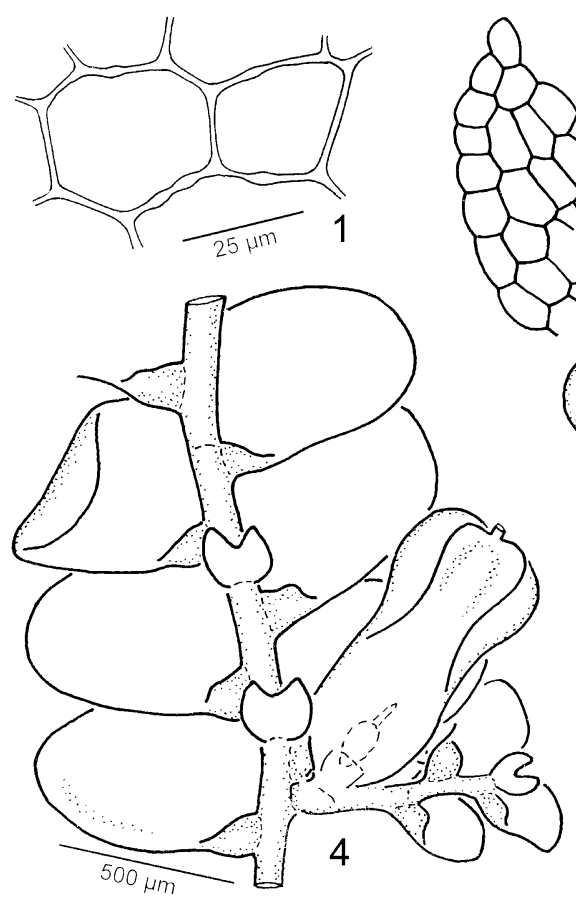

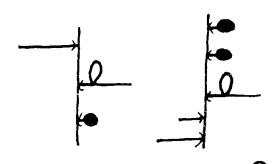

3
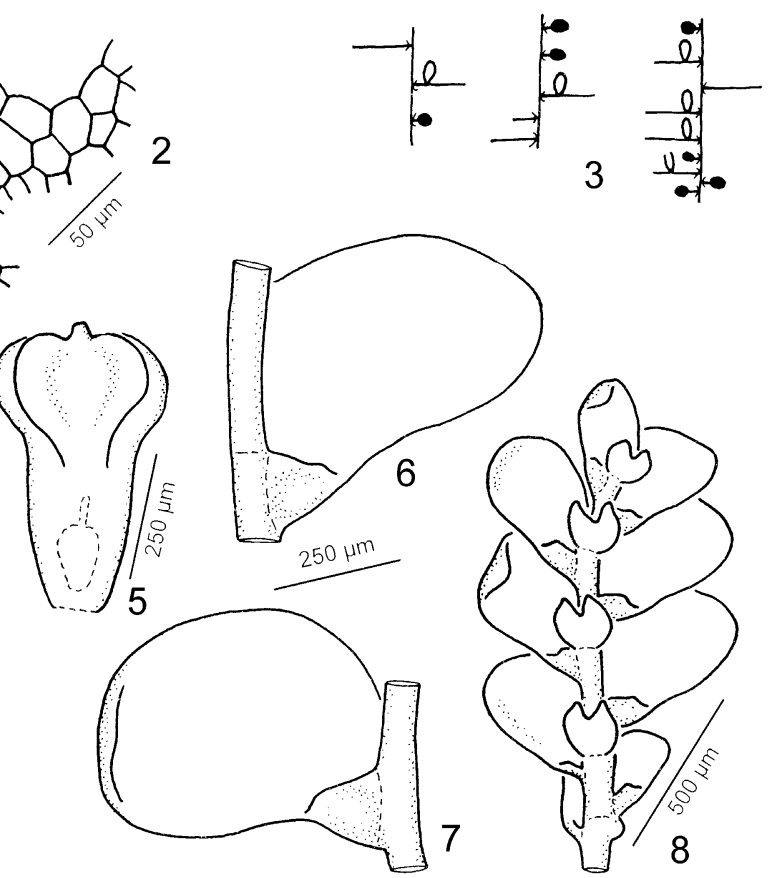

Fig. 2. Lejeunea tonduzana (Steph.) M. E. Reiner. 1 - median leaf cells, 2 - part of underleaf, 3 - cladographs of fertile plants (solid ellipse $=$ androecium, open ellipse $=$ gynoecium with perianth, $\mathrm{U}=$ gynoecium without perianth), $4-$ sector of shoot with mature perianth, ventral view, 5 - perianth, ventral view, $6 \& 7$ - leaves, 8 - sector of shoot, ventral view. (All from G11832, holotype). 
at the upper part, 550-900 $\mu \mathrm{m}$ long, 5-keeled, keels $\pm 1 / 2$ the length of the perianth, all keels equally developed, \pm inflated and expanded, entire, slightly crenate, (probably) not winged, beak $35 \mu \mathrm{m}(1-2$ cells) long. Vegetative reproduction not observed. Sporophyte not observed.

DISTRIBUTION AND ECOLOGY. Lejeunea tonduzana is only known from the type material, collected in Costa Rica, at 200-250 m. It was growing as an epiphyll on fern, together with $L$. adpressa and Radula sp.

DISCUSSION. Two fertile species of Lejeunea are growing intermixed in the type sample of $\mathrm{Hy}$ grolejeunea tonduzana. The plants with 5-keeled and inflated perianths are those specimens described and illustrated by Stephani as H. tonduzana (Stephani 1985, nr. 4363). The second species, Lejeunea adpressa, has a dorsally compressed perianth (Reiner-Drehwald 2009).

Lejeunea tonduzana is characterized by the strongly inflated perianth, with the keels expanded in the upper $1 / 3$. The female bracts and bracteoles are broken and could not be described. Dauphin (2005: 208) described the androecia of Hygrolejeunea tonduzana as "Androecia terminal on main branches or on the gynoecial innovations!, with 1-3 bract pairs". In the studied plants the androecia are terminal on short branches and the observations of Dauphin could not be confirmed. However, additional collections are needed to determine the morphological plasticity of this species.

\section{Lejeunea recurva M. E. Reiner, nom. nov.}

Fig. 3

$\equiv$ Hygrolejeunea recurva Steph. nom. herb. Hygrolejeunea recurva Steph. ex Bonner, Index Hepaticarum 6: 653,663 . 1966, nom. inval. nom. nud., Art. 32.1 Melbourne Code.

$\equiv$ Hygrolejeunea herzogii Steph. in Herzog, Biblioth. Bot. 87: 265. 1916, nom. illeg., later homonym, Art. 53.1 Melbourne Code. Non Hygrolejeunea herzogii Steph., Spec. hepat. 5: 530. 1914 (= Lejeunea catinulifera Spruce, see Reiner-Drehwald 2005). Non Lejeunea herzogii Mizut. 1967 (TYPE: Indonesia; = Lejeunea papilionacea Steph., see Zhu \& Grolle 2001).
TyPE. BOLIVIA. Santa Cruz, prov. Caballero, Sillar, 1800 m, 1911, Herzog 2687 (HOLOTYPE, G [c. per.]; ISOTYPE, JE [c. per.]).

Plants dull to shiny, yellowish green in herbarium, 1.5-2.0 mm wide; branches of the Lejeunea-type, few, smaller than the main shoot, 1.0-1.3 mm wide, collars large. Stems $140-200 \mu \mathrm{m}$ wide, epidermal cells in ventral view rectangular, $70-75 \times 80-100 \mu \mathrm{m}$; stems in cross section suborbicular, epidermis of 7 rows of enlarged cells surrounding \pm 70 rows of small medullary cells, epidermal cells $40-50 \times 85-105 \mu \mathrm{m}$, medullary cells $15-25 \times 20-30 \mu \mathrm{m}$, cell walls thin, hyaline to yellowish; ventral merophyte 2 cells wide. Leaves imbricate, obliquely to widely spreading. Lobes ovate, \pm concave, $850-1200 \mu \mathrm{m}$ long, $700-900 \mu \mathrm{m}$ wide, margin entire, apex rounded, recurved, dorsal margin arched, ventral margin slightly arched. Marginal leaf cells quadrate to rectangular, 10-18 $\times 17-25 \mu \mathrm{m}$; median leaf cells isodiametric to elongated, $20-25 \times 30-35 \mu \mathrm{m}$; basal cells elongated, 30-33 $\times 40-50 \mu \mathrm{m}$; cell walls thin, trigones medium-sized, intermediate thickenings common, (0-)1-2(-3) per wall, cuticle papillose; oil bodies not observed. Lobules variable, when well developed, \pm rectangular to triangular, strongly inflated, 130-140 $\mu \mathrm{m}$ long, 100-125 $\mu \mathrm{m}$ wide, $<1 / 6$ the lobe length, lateral margin inrolled or the distal portion with the tooth seen in situ, lateral margin 5-6 cells long, tooth oval, hyaline papillae obovoid, at the proximal base of the tooth, apical margin lunulate to straight, 2-3 cells long, keel straight to slightly arched, \pm crenate, at the union with ventral margin of lobe slightly angled; reduced lobules variable in shape and size. Underleaves imbricate to contiguous, appressed on the stem, central part between rhizoid disc and sinus \pm convex, reniform, 600-1100 $\mu \mathrm{m}$ wide, 400-700 $\mu \mathrm{m}$ long, wider than long, 4-5 $\times$ the stem width, $15-25 \%$ bifid, sinus V-shaped, narrow, lobes triangular, connivent, apex acute, ending in 1 cell, margins entire, apical half recurved, base auriculate, insertion line slightly arched, rhizoid disc pronounced. Dioicous? Androecia not observed. Gynoecia terminal on branches or on the main stem, 1-2 innovations, gynoecial pattern often dichasial, up to 3 gynoecia in a row. Female bract lobes oval, 600-1000 $\mu \mathrm{m}$ long, 


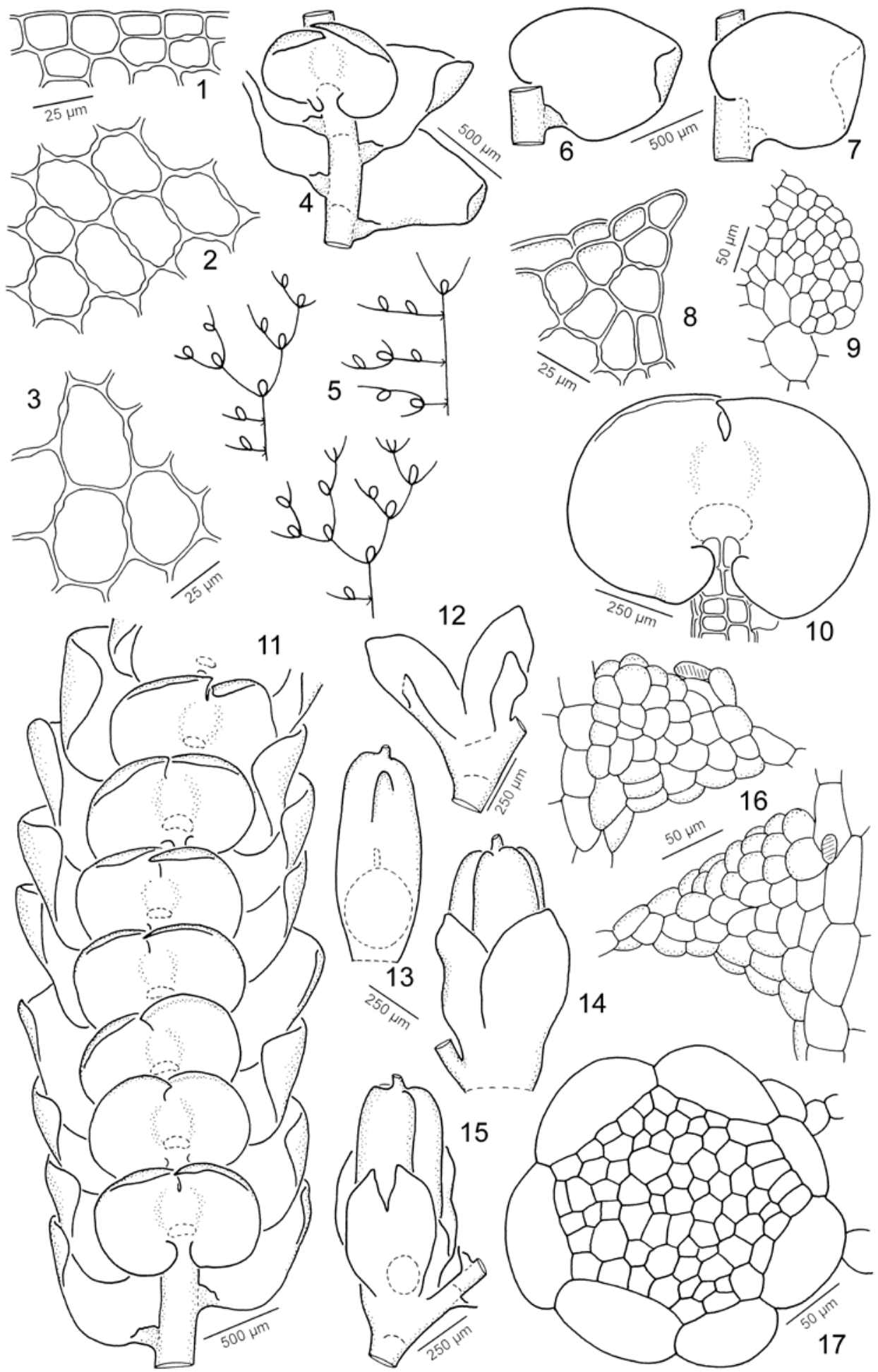


250-370 $\mu \mathrm{m}$ wide, margin slightly crenate, apex rounded to subacute; bract lobules oval to rhomboidal, 400-700 $\mu \mathrm{m}$ long, $120 \mu \mathrm{m}$ wide, margin slightly crenate, apex subacute, keel straight, not winged; female bracteole oval, 400-600 $\mu \mathrm{m}$ wide, 550-800 $\mu \mathrm{m}$ long, free, $20-35 \%$ bifid, sinus Vshaped, lobes acute. Perianth 1/3-1/2 emergent between the bracts, cylindrical to ellipsoidal, not compressed, 350-400 $\mu \mathrm{m}$ wide, $800-900 \mu \mathrm{m}$ long, 5-keeled to $1 / 3-1 / 2$ the length of the perianth, all keels equally developed, keels entire, not winged, perianth surface papillose, beak 60-75 $\mu \mathrm{m}$ (2-4 cells) long. Vegetative reproduction not observed. Sporophytes not observed.

DistRIBUTION AND ECOLOGY. Lejeunea recurva is until now known only from the Andes in Bolivia (type material, with perianths) and Peru (sterile), between 1300-1800 m, where it was growing as an epiphyte.

ADDITIONAL SPECIMEN EXAMINED: PERU. SAN MARTín: prov. Rioja, distrito Pardo Miguel, near bridge Serranoyacu, 1300-1400 m, 05 $40^{\prime} 32^{\prime \prime} \mathrm{S}, 77^{\circ} 40^{\prime} 28^{\prime \prime} \mathrm{W}$, 8 Jan. 2001, Drehwald 4870 (USM, GOET).

DISCUSSION. Lejeunea recurva is easily recognized by the large and reniform underleaves, which are shortly bifid and recurved at the upper half. The leaf lobes are also recurved, the lobules small, less than $1 / 6$ the lobe length, the cells are thin walled, with trigones and intermediate thickenings and papillose cuticle. Androecia where not observed; the female plants often possess a characteristic dichasial gynoecial pattern, the perianths are long, cylindrical and the 5 keels are entire.

The species resembles Lejeunea reflexistipula (Lehm. \& Lindenb.) Gottsche et al., mainly by the large and reniform underleaves, but in the latter they are entire and the bases are rounded, whereas in L. recurva the bifid underleaves have large auriculate bases (Reiner-Drehwald 2005).

\section{Lejeunea cerina (Lehm. \& Lindenb.) Gottsche}

Lindenb. \& Nees, Syn. Hep.: 391. 1845. Jungermannia cerina Lehm. \& Lindenb. in Lehmann, Nov. Stirp. Pug. 5: 16. 1833. Hygrolejeunea cerina (Lehm. \& Lindenb.) Schiffner in Engler \& Prantl, Nat. Pflanzenfam. 1(3): 125. 1893 (Preprint). Macrolejeunea cerina (Lehm. \& Lindenb.) Gradst., Bryologist 92: 345. 1989. TYPE: BRAZIL. Rio de Janeiro: Serra dos Orgãos, Beyrich s.n. (LECTOTYPE, S, not seen, designated by Grolle 1987: 440; ISOLECTOTYPE, U [sterile, few stems]).

= Hygrolejeunea aspera Steph., Spec. hepat. 5: 543 . 1914. TYPE. MEXICO. Veracruz: Zacuapan, Liebman 539 b, ex Herb. Lindenberg 6741 (HOLOTYPE, G 27315 [gyn.]); syn. nov.

= Hygrolejeunea similis Steph., Spec. hepat. 5: 541. 1914. TYPE. COSTA RICA. Buenos Aires, 1892, Tonduz 15553 (HOLOTYPE, G 11817 [gyn.]); syn. nov.

\section{Lejeunea flava (Sw.) Nees}

Naturgesch. Eur. Leberm. 3: 277. 1838. Jungermannia flava Sw., Nova Gen. Spec. P1. Prodr.: 144. 1788. TYPE. JAMAICA. Swartz s.n. (LECTOTYPE, UPS [Hb. Thunb. 25916, c.per.], not seen, designated by Grolle 1976: 201; ISOLECTOTYPES, S [scanty, 2 shoots], BM [c.per.]).

= Hygrolejeunea bahiensis Steph., Hedwigia 35: 99. 1896. TYPE. BRAZIL. Bahia, Didrichsen s.n. (HOLOTYPE, $\mathrm{G}$ [scanty, 4 shoots, autoicous, c.gyn.]; syn. nov.

ACKNOWLEDGMENTS. To the Deutsche Forschungsgemeinschaft (DFG RE 1348/4-1) for financial support to the first author. To the Smithsonian Tropical Research Institute for financial support for research on tropical bryophytes to Noris Salazar Allen and her former Research Assistant Clementina Chung C. ( $\dagger$ ), to personnel of Barro Colorado Island for support during our studies of the bryophytes of the Island, and to ANAM (Autoridad Nacional del Ambiente) in Panama for collecting permits. To Gregorio Dauphin (Costa Rica), and an anonymous reviewer for helpful comments. We are also grateful to the curators and directors of G, GOET, JE, MANCH, NY, P, PMA, and USM for the loan of herbarium material, including many types.

Fig. 3. Lejeunea recurva M. E. Reiner. 1 - marginal leaf cells, 2 - median leaf cells, 3 - basal leaf cells, 4 - shoot sector, two underleaves removed, ventral view, 5 - cladographs of fertile plants (open ellipse = gynoecium with perianth), $6-$ leaf, ventral view, 7 - leaf, dorsal view, 8 - underleaf lobe apex, 9 - underleaf base, 10 - underleaf, 11 - shoot sector, ventral view, 12 - female bracts, 13 - perianth, dorsal view, $14 \& 15$ - perianth with bracts (14 in dorsal view, 15 in ventral view), 16 - leaf lobules, 17 - cross section of stem. (4, 9, 12-15 from JE, isotype; 5 from G, holotype; 1-3, 6-8, 10, 11, 16, 17 from Drehwald 4870, GOET). 


\section{REFERENCES}

ANONYMOUS 1992. Protected Areas of the World. A review of national systems. Volume 4. Nearctic and Neotropical. IUCN - The World Conservation Union, Gland, Switzerland and Cambridge, UK.

CROAT T. B. 1978. Flora of Barro Colorado Island. Stanford University Press. Stanford, California, USA.

DAuphin G. 2005. Catalogue of Costa Rican Hepaticae and Anthocerotae. Trop. Bryol. 26: 141-218.

DAUPHIN G. 2007. Nuevas adiciones de especies de hepáticas para la flora de Panamá. Candollea 62: 45-51.

Dauphin L. G., Pócs T., Villarreal J. C. \& Salazar Allen N. 2006. Nuevos Registros de Hepáticas y Anthocerotófitas para Panamá. Trop. Bryol. 27: 73-85.

GROLLE R. 1976. Verzeichnis der Lebermoose Europas und benachbarter Gebiete. Feddes Repert. 87: 171-279.

Grolle R. 1987. Miscellanea hepaticologica 251-260. J. Hattori Bot. Lab. 63: 437-443.

Grolle R. 1988. Zur Kenntnis der Lejeuneoideae in Cuba (2): Lejeunea subg. Macrolejeunea Spruce. Wiss. Z. Friedrich-Schiller-Univ. Jena, Math. Naturwiss. Reihe 37: 169-176.

HeInRICHS J., DONG S., FeldBerg K., SchÄFER-VERWIMP A. $\&$ SCHMIDT A. R. 2012. Sphaerolejeunea (Lejeuneaceae, Porellales) is a synonym of Lejeunea. Phytotaxa 69: 7-15.

LEIGH E. G, RAND A. S. \& Windsor D. M. 1983. The Ecology of Neotropical Forest: Seasonal Rythms and Longer Term Fluctuations. Smithsonian Institution Press. Washington DC, USA.

Pócs T. 2010. On some new or less known Lejeunea (Lejeuneaceae, Jungermanniopsida) species in tropical Africa. East African Bryophytes, XXVII. Nova Hedwigia Beih. 138: 99-116.

REINER-DREHWALD M. E. 1999. Catalogue of the genus Lejeunea Lib. (Hepaticae) of Latin America. Bryophyt. Biblioth. 54: 1-101.

REINER-DREHWALD M. E. 2000. Las Lejeuneaceae (Hepaticae) de Misiones, Argentina. VI. Lejeunea y Taxilejeunea. Trop. Bryol. 19: 81-131.

ReINER-DrehWALd M. E. 2005. On Amphilejeunea and Cryp- togynolejeunea, two small genera of Lejeuneaceae (Jungermanniopsida), and two common neotropical Lejeunea species. Nova Hedwigia 81: 395-411.

ReINER-Drehwald M. E. 2009. Lejeunea adpressa Nees (Lejeuneaceae), a widely distributed species of tropical America. Cryptog. Bryol. 30: 329-336.

REINER-DREHWALD M. E. 2011. Studies on Neotropical Lejeuneaceae (Jungermanniopsida). New synonyms and Ceratolejeunea temnantha (Spruce) comb. nov. Cryptog. Bryol. 32: 95-100.

REINER-DrehWALD M. E. \& GodA A. 2000. Revision of the genus Crossotolejeunea (Lejeuneaceae, Hepaticae). J. Hattori Bot. Lab. 89: 1-54.

ReIner-Drehwald M. E. \& IlKIU-Borges A. L. 2007. Lejeunea huctumalcensis, a widely distributed Lejeuneaceae from the Neotropics, and its relation to Ceratolejeunea. Bryologist 110: 465-474.

Reiner-Drehwald M. E. \& Mustelier Martínez K. 2004. On Lejeunea multidentata, a new species from Cuba (Jungermanniopsida: Lejeuneaceae). J. Bryol. 26: 103-106.

REINER-DREHWALD M. E. \& SCHÄFER-VERWIMP A. 2008. On Inflatolejeunea, Lejeunea species with eplicate perianths and Lejeunea talamancensis sp. nov. from Costa Rica (Lejeuneaceae). Nova Hedwigia 87: 387-420.

Renner M. A. M., Brown E. A. \& Wardle G. M. 2011. The Lejeunea tumida species group is positively polyphyletic (Lejeuneaceae: Jungermanniopsida). Austral. Syst. Bot. 24: 10-18.

SCHÄFER-VERWIMP A. 2012. Cololejeunea tamasii (Lejeuneaceae, Marchantiophyta), a new species from Panama. Phytotaxa 60: 9-12.

StePHANI F. 1985. Icones Hepaticarum. Microfiche ed. IDC, Leiden.

Stotler R., Salazar Allen N., Gradstein S. R., McGuinNESS W., WhitTEMORE A. \& CHUNG C. 1998. A checklist of the hepatics and Anthocerotes of Panama. Trop. Bryol. 15: $167-195$.

ZHU R.-L. \& GROLLE R. 2001. Notes on the taxonomy and distribution of Acanthocoleus yoshinaganus and Lejeunea papilionacea (Hepaticae, Lejeuneaceae). Ann. Bot. Fennici 38: 329-336. 